Iva Tuhtan Grgić, Ph. D.

E-mail: ituhtan@pravri.hr

University of Rijeka, Faculty of Law, Hahlić 6, 51000 Rijeka, Croatia

\title{
O nekim aspektima i implikacijama pravnog statusa odobalnih objekata za istraživanje i eksploataciju ugljikovodika u Republici Hrvatskoj
}

\section{Sažetak}

Svrha ovoga rada je istražiti i odrediti pravni status odobalnih objekata za istraživanje i eksploataciju ugljikovodika prema hrvatskom pravu. Naime, analiza odredaba Zakona o istraživanju i eksploataciji ugljikovodika, kojima je uređena ta djelatnost, pokazala je da pravni status tih objekata nije reguliran, što nameće potrebu da se utvrdi pod koje se norme može podvesti te objekte, odnosno koje odredbe treba odgovarajuće primijeniti za određivanje njihova pravnog statusa, posebice u smislu utvrđivanja jesu li ti objekti pokretnine ili nekretnine. Jasno određivanje pravnog statusa odobalnih objekata za istraživanje i eksploataciju ugljikovodika od iznimne je važnosti, ne samo za potencijalne investitore, postojeće koncesionare, ovlaštenike dozvola i Republiku Hrvatsku, već i za sve treće s obzirom da će o pravnom statusu odobalnih objekata ovisiti, primjerice, primjena odredaba o izvanugovornoj odgovornosti za štetu, kao i primjena instituta ograničenja te odgovornosti.

Uvodno se naglašava da se istraživanje i eksploatacija ugljikovodika iz podmorja može izvoditi s odobalnih objekata koji su po svojim tehničkim karakteristikama toliko različiti da je upitno može li se na sve te objekte primijeniti isti pravni režim. To posebice imajući u vidu i to da pravni status odobalnog objekta može ovisiti o tomu je li odobalni objekt u određenom trenutku u funkciji istraživanja i eksploatacije ugljikovodika ili je u postupku premještanja s jedne lokacije na drugu.

Vodeći se navedenim specifičnostima, autorica analizira hoće li se, u konkretnom slučaju, u odnosu na neki odobalni objekt primijeniti odredbe Zakona o rudarstvu (na koje upućuje osnovni Zakon o eksploataciji i istraživanju ugljikovodika) koje uređuju status rudarskih objekata i postrojenja, ili odredbe Pomorskog zakonika o pomorskim objektima, s obzirom da se ta djelatnost obavlja na moru. Ističe se i to da Pomorski zakonik razlikuje tri vrste pomorskih objekata - plovni objekt (brod), plutajući objekt i nepomični odobalni objekt pa se kao dodatno postavlja pitanje pod koju bi se vrstu pomorskog objekta mogao podvesti odobalni objekt za istraživanje i eksploataciju ugljikovodika. Radi određivanja pravne kvalifikacije pojedinog odobalnog objekta kao pokretnine ili nekretnine odgovor se traži i u općem propisu - Zakonu o vlasništvu i drugim stvarnim pravima.

Cilj je ovoga rada ukazati na pravne praznine zakonskog okvira kojim je uređena djelatnost istraživanja i eksploatacije ugljikovodika te upozoriti na

moguće neočekivane i neželjene pravne učinke popunjavanja tih praznina supsidijarnim propisima, neprilagođenima specifičnostima te djelatnosti. Stoga autorica sugerira da se pitanje pravnog statusa, ali i neka druga područja u odnosu na koja je uočena podnormiranost ili nedosljednost, uredi na jasan način, u posebnom propisu kojim je uređena materija istraživanja i eksploatacije ugljikovodika.

Ključne riječi: pravni status, platforme, odobalni objekti, istraživanje i eksploatacija ugljikovodika 


\section{Uvod}

Planirani projekt istraživanja i eksploatacije ugljikovodika u Jadranu aktualizirao je potrebu izučavanja pravne regulative vezane uz tu djelatnost. Temeljni propis kojim je uređena ta materija je Zakon o istraživanju i eksploataciji ugljikovodika, ${ }^{1,2}$ koji upućuje na supsidijarnu primjenu Zakona o rudarstvu ${ }^{3}$ i propisa donesenih na temelju ZR-a. Pored toga, donesena su još dva propisa kojima su regulirana pitanja sigurnosti i tehničkih zahtjeva koje moraju ispunjavati ovlaštenici dozvola i izvođači radova. To su Zakon o sigurnosti pri odobalnom istraživanju i eksploataciji ugljikovodika ${ }^{4,5}$ i Pravilnik o bitnim tehničkim zahtjevima, sigurnosti i zaštiti pri istraživanju i eksploataciji ugljikovodika iz podmorja Republike Hrvatske. ${ }^{6}$ Pravni okvir za obavljanje djelatnosti istraživanja i eksploatacije ugljikovodika iz hrvatskog podmorja koji čine navedeni zakoni u nekim je važnim dijelovima podnormiran. Takva podnormiranost postoji upravo u odnosu na pitanje pravnog statusa odobalnih objekata koja se mora prevladati primjenom odredaba supsidijarnih zakona, u prvom redu Pomorskog zakonika, ${ }^{7}$ a potom i Zakona o vlasništvu i drugim stvarnim pravima.8 Pitanje pravnog statusa tih objekata bilo bi čisto doktrinarno u slučaju da je pravni okvir temeljit i sveobuhvatan. Međutim, upravo zbog nedorečenosti odredaba ZIEU, otvorit će se, u pokušaju razrješenja dvojbi i eventualnih sporova, pitanje da li je neki odobalni objekt pokretnina (i ako jest, da li je brod ili neki drugi pomorski objekt) ili nekretnina. U ovisnosti o odgovoru na postavljeno pitanje doći će do primjene različita pravila kod odlučivanja o izvanugovornoj odgovornosti za štete, plaćanja komunalnih i vodnih doprinosa, prelaska prava vlasništva nad tim objektima (a time i odgovornosti) na Republiku Hrvatsku u slučaju ukidanja dozvole i/ili raskida ugovora itd.

Postojanje više supsidijarnih zakona primjena kojih dovodi do bitno različitih zaključaka daje pitanju pravnog statusa objekata s kojih se obavlja istraživanje i eksploatacija ugljikovodika iz podmorja praktičan značaj i nameće potrebu detaljne analize navedenih odredaba te ukazivanja na moguće posljedice takvih dvojnih režima i potrebu da se to pitanje uredi na jasan i nedvojben način.

NN, br. 94/13, 14/14 (u daljnjem tekstu: ZIEU).

2 Odredbe ZIEU-a usklađene su s Direktivom 94/22/EZ Europskog parlamenta i Vijeća od 30. svibnja 1994. o uvjetima za davanje i korištenje odobrenja za traženje, istraživanje i proizvodnju ugljikovodika (SL L 164., od 30. lipnja 1994.).

3 NN, br. 56/13, 14/14 (u daljnjem tekstu: ZR).

$4 \quad \mathrm{NN}$, br. 78/15 (u daljnjem tekstu: Zakon o sigurnosti).

5 Zakon o sigurnosti donesen je radi usklađivanja hrvatskog prava s Direktivom 2013/30/EU Europskog parlamenta i Vijeća o sigurnosti od odobalnih naftnih i plinskih djelatnosti i o izmjeni Direktive 2004/35/EZ (SL L 302., od 22. listopada 2014.).

6 NN, br. 52/10 (u daljnjem tekstu: Pravilnik o bitnim tehničkim zahtjevima ili Pravilnik).

7 NN, br. 181/04, 76/07, 146/08, 61/11, 56/13, 26/15 (u daljnjem tekstu: PZ).

8 NN, br. 91/96, 68/98, 137/99, 22/00, 73/00, 114/01, 79/06, 141/06, 146/08, 38/09, 153/09, 90/10, 143/12, 152/14 (u daljnjem tekstu: ZV ili Zakon o vlasništvu). 
Vrste odobalnih objekata za istraživanje i eksploataciju ugljikovodika iz podmorja brojne su i mogu se, među ostalim, podijeliti prema njihovoj pokretljivosti te načinu održavanja u položaju za istraživanje i eksploataciju. Najveći stupanj pokretljivosti svakako imaju brodovi za bušenje, tzv. drilling ships, koji su autonomne pokretne plovne jedinice s vlastitim sustavom propulzije te koji su po svojoj strukturi (i imenu) brodovi. Za razliku od bušaćih brodova, poluuronjive se platforme tegle na eksploatacijsko polje, gdje se tijekom rada, poput brodova za bušenje, održavaju na morskoj površini vlastitim uzgonom, a na mjestu su učvršćene sidrenjem ili dinamičkim pozicioniranjem. Poduprte platforme (tzv. jack-up) (samopodizna i uronjiva) također su pokretne, i na novu se lokaciju mogu premještati isključivo tegljenjem, uz pomoć remorkera, pri čemu ih na površini mora održava uzgon. Međutim, za razliku od poluuronjivih platformi te su platforme tijekom rada čeličnim ili armiranobetonskim nogama poduprte o morsko dno ili ukopane u njega. Navedena podjela, koja pokazuje izuzetnu tehničku raznolikost objekata s kojih se može obavljati istraživanje i eksploatacija ugljikovodika iz podmorja, te činjenica da svaki od navedenih objekata može biti u funkciji iskorištavanja i/ili eksploatacije ugljikovodika, ali i u postupku transporta s jedne lokacije na drugu, nameće pitanje primjenjivosti istog pravnog statusa na sve te objekte.

Stoga će se u radu pokušati odgovoriti na pitanje može li se (ili mora) pojedine vrste platformi smatrati brodom ${ }^{9}$ ili nekom drugom vrstom pomorskog objekta pa na njih primjenjivati odredbe PZ-a ili se, u pogledu njihova pravnog statusa, treba primijeniti odredbe ZR-a ili, pak, opće odredbe Zakona o vlasništvu.

\section{Pravni status odobalnih objekata za istraživanje i eksploataciju ugljikovodika iz podmorja u hrvatskom zakonodavstvu}

\subsection{Pravni status odobalnih objekata prema zakonskom okviru o djelatnosti istraživanja i eksploatacije ugljikovodika}

Odredbama ZIEU-a i ZR-a, kao temeljnim propisima kojima je regulirana ova djelatnost, uređena su razna pitanja istraživanja i eksploatacije ugljikovodika koji se nalaze u zemlji ili u podzemlju unutarnjih morskih voda ili teritorijalnog mora Repu-

Pojam broda je već sam po sebi dvojben u pravnoj teoriji, ali i u konvencijskim tekstovima u kojima su, ovisno o svrsi konvencije, pojmom brod obuhvaćane samo neke vrste brodova (primjerice za potrebe Konvencije o građanskoj odgovornosti za štetu prouzročenu onečišćenjem uljem - CLC Convention, 1992., NN-MU, br. 2/97, 3/99, brodom se smatra svaki brod ili plovilo bilo koje vrste konstruirano ili prilagođeno za prijevoz ulja u rasutom stanju kao teret, i to samo ako stvarno takvo ulje prevozi (čl. 1. st. 1.)) ili pak sadrže široku definiciju broda pod koju potpadaju i ostale vrste plovnih objekata, pa čak i pričvršćene i ploveće platforme (tako primjerice u čl. 2. st. 1. t. 4. MARPOL-a, Sl.1. SFRJ-MU, br. 2-14/85, S1.1. SFRJ-MU, br. 2-15/85, NN-MU, br. 1/92 i NN-MU, br. 4-43/2005). O teorijskim raspravama i tumačenjima pojma broda vidjeti: Grabovac, I., Pravna problematika istraživanja i iskorištavanja podmorja s posebnim osvrtom na odgovornost za štetne posljedice, Split, 1983., str. 33-36. i tamo citirana literatura. 
blike Hrvatske, odnosno u podzemlju epikontinentalnog pojasa Jadranskog mora do linije razgraničenja sa susjednim zemljama na kojima Republika Hrvatska, u skladu s međunarodnim pravom, ostvaruje jurisdikciju i suverena prava. ${ }^{10}$ Pojmovi 'istraživanje ugljikovodika' i 'eksploatacija ugljikovodika' obuhvaćaju čitav spektar radnji definiranih u odredbama čl. 4. st. 1. t. $4 .{ }^{11}$ i $10 .{ }^{12}$ ZIEU-a. Međutim, odredbe navedenih zakona ne čine razliku između djelatnosti istraživanja i eksploatacije ugljikovodika na moru od onoga na kopnu, niti sadrže posebne odredbe o rudarskim objektima i postrojenjima na moru, iako bi za posebno uređenje postojali opravdani razlozi, kako zbog specifičnosti morskog ambijenta, čije istraživanje i eksploatacija sa sobom nosi veće rizike - rizike onečišćenja morskog okoliša, tako i zbog činjenice da su objekti kojima se obavljaju te djelatnosti po svojim tehničkim obilježjima bitno različiti od onih kojima se obavlja istraživanje i eksploatacija na kopnu. ${ }^{13}$

Ako se ima na umu definicija pojmova istraživanje ugljikovodika i eksploatacija ugljikovodika (supra bilj. 11 i 12) jasno je da se za obavljanje tih djelatnosti koristi čitav niz objekata - od platformi s kojih se vrši samo istraživanje i/ili eksploatacija (odobalni objekti za istraživanje i eksploataciju u užem smislu) preko objekata za skladištenje i preradu ugljikovodika do cjevovoda za transport ugljikovodika do kopna (odobalni objekti za istraživanje i eksploataciju u širem smislu). Predmet ovoga rada je samo analiza pravnog statusa odobalnih objekata u užem smislu.

Ukazano je već na to da iz odredaba ZIEU-u i ZR-a proizlazi da je i pravni status objekata za istraživanje i eksploataciju ugljikovodika na kopnu i moru jednak. U oba

$10 \quad$ Područje primjene ZR-a nešto je šire no ZIEU-a, i to u dva smjera - ZR se odnosi na istraživanje i eksploataciju svih mineralnih sirovina nabrojanih u čl. 5. ZR-a, a ne samo na ugljikovodike, te obuhvaća njihovo istraživanje i eksploataciju i kada se nalaze na površini zemlje, na riječnom, jezerskom ili morskom dnu.

11 Radnje istraživanja uključuju istražne i ocjenske radove i djelatnosti koje su definirane u odobrenom programu rada, a kojima je cilj utvrditi postojanje, položaj i oblik ležišta ugljikovodika, njihovu količinu i kakvoću te uvjete eksploatacije, radove i ispitivanja kojima je svrha utvrditi mogućnost skladištenja ugljikovodika i trajnog zbrinjavanja plinova u geološkim strukturama te uvjete eksploatacije, uključujući geofizička i geološka snimanja, bušenje, produbljivanje, skretanje, opremanje, ispitivanje, privremeno napuštanje, likvidaciju istražnih bušotina, ali i kupnju i nabavu roba, usluga, materijala i opreme potrebne za spomenute radove.

12 Pojmom eksploatacija ugljikovodika obuhvaćene su radnje pridobivanja ugljikovodika iz ležišta i oplemenjivanja ugljikovodika, transport ugljikovodika cjevovodima, kada je u tehnološkoj svezi s odobrenim eksploatacijskim poljima, skladištenje ugljikovodika i trajno zbrinjavanje plinova u geološkim strukturama.

13 Ta specifičnost i osjetljivost morskog okoliša te potreba posebnog uređenja prepoznata je u Zakonu o sigurnosti, Pravilniku o bitnim tehničkim zahtjevima i Pravilniku o zaštiti morskog okoliša u zaštićenom ekološko-ribolovnom pojasu Republike Hrvatske (NN, br. 47/08). Odredbom čl. 4. Pravilnika o zaštiti morskog okoliša propisano je da fiksne i plutajuće platforme, uključujući platforme za bušenje, plutajuća sredstva za proizvodnju, skladištenje $i$ iskrcavanje koje se koriste za odobalnu proizvodnju i skladištenje ulja i plutajuće skladišne jedinice za odobalno skladištenje proizvedenog ulja, kao i platforme za proizvodnju plina, moraju udovoljavati zahtjevima Pravila 39. Poglavlja 7. Priloga I MARPOL Konvencije, te Protokola Barcelonske konvencije o odobalnim objektima. Zanimljivo je ovdje istaći da Republika Hrvatska nije ratificirala Barcelonsku konvenciju o odobalnim objektima pa je upitno kako bi se njezine odredbe uopće primjenjivale. 
su zakona pojmom 'rudarski objekti i postrojenja' obuhvaćeni svi objekti, postrojenja, oprema, alati, uređaji i instalacije koji se koriste kod izvođenja istraživanja i eksploatacije (čl. 4. st. 1. t. 28. ZIEU), odnosno kod rudarskih radova (čl. 13. ZR), dok je odredbama čl. 105.-139. ZR-a uređena materija građenja rudarskih objekata i postrojenja. Budući da je PZ-om propisano da Republika Hrvatska ima isključivo pravo graditi, dopuštati i regulirati gradnju, rad i uporabu postrojenja i uređaja za iskorištavanje prirodnih bogatstava epikontinentalnog pojasa Republike Hrvatske, odgovarajućom primjenom propisa Republike Hrvatske (arg. ex. čl. 35. st. 1. i 2. PZ i 45. st. 2. PZ), građenje tih objekata provodit će se primjenom odredaba ZR-a i ZIEU-a. Građenje i stručni nadzor nad građenjem rudarskih objekata i postrojenja koncesionar mora povjeriti osobama koje ispunjavaju uvjete za obavljanje tih djelatnosti sukladno ZR-u (čl. 4. st. 1. t. 28. i 29. ZIEU, čl. 4. i 74. st. 3. Pravilnika i čl. 110. ZR).

Za građenje rudarskih objekata i postrojenja potrebna je građevinska dozvola koju izdaje tijelo nadležno za rudarstvo (čl. 105. ZR). Budući da su terminom rudarski objekti i postrojenja obuhvaćeni svi objekti koji se koriste kod istraživanja i eksploatacije, neovisno o tehničkim obilježjima objekta, investitor će, u svakom slučaju, morati podnijeti zahtjev za izdavanje građevinske dozvole.14 Zahtjevu moraju biti priložena tri primjerka glavnog projekta građenja rudarskih objekata i postrojenja s uvezanom lokacijskom dozvolom, 15 zemljovid s ucrtanim granicama eksploatacijskog polja, na kojem su razvidne sve zemljišne čestice ili pozicije na službenoj pomorskoj navigacijskoj karti morskog dijela eksploatacijskog polja koje su u obuhvatu predmetne građevinske dozvole, ugovor o koncesiji i dokaz da ima pravo graditi rudarske objekte i postrojenja (čl. 118. st. 2. ZR). Iz formulacije odredbe čl. 118. ZR-a proizlazi da se njegove odredbe primjenjuju i na odobalne objekte. Dokazom da investitor ima pravo graditi rudarske objekte i postrojenja drži se osobito 'ugovor ili odluka nadležnog državnog tijela na temelju koje je fizička osoba ili pravna osoba stekla pravo vlasništva,

14 Istraživanje i eksploatacija ugljikovodika dozvoljeni su samo unutar utvrđenog istražnog prostora, odnosno eksploatacijskog polja ugljikovodika, a za eksploataciju je propisano da je dozvoljena samo u granicama provjerenog rudarskog projekta. Iako bi iz navedenog proizlazilo da za fazu istraživanja nije potreban rudarski projekt, zbog opisa radnji obuhvaćenih fazom istraživanja s time se ne bi mogli složiti.

15 Lokacijsku dozvolu za građevinu za eksploataciju na eksploatacijskom polju mineralnih sirovina izdaje Ministarstvo zaštite okoliša, prostornog uređenja i graditeljstva na temelju odredbe čl. 4 . Uredbe o određivanju zahvata u prostoru i građevina za koje Ministarstvo zaštite okoliša, prostornog uređenja i graditeljstva izdaje lokacijsku i/ili građevinsku dozvolu. NN, br. 116/07, 56/11. Odredbom čl. 102. PZ-a propisano je kojim uvjetima treba udovoljavati plutajući objekt i nepomični odobalni objekt da bi bio sposoban za uporabu. U st. 3. istog članka propisano je da kada se takav objekt postavlja ili upotrebljava u unutrašnjim morskim vodama ili teritorijalnom moru Republike Hrvatske, osim plutajućeg objekta koji se postavlja ili upotrebljava u luci, mora zadovoljavati uvjete određene lokacijskom dozvolom, odnosno detaljnim planom uređenja. Za sve objekte koji se grade na unutarnjim morskim vodama i u teritorijalnom moru, odnosno na njihovim obalama nadležno tijelo, investitor ili druga zainteresirana stranka je dužno u postupku izdavanja dozvola propisanih posebnim propisima kojima se regulira prostorno uređenje i gradnja ishoditi suglasnost lučke kapetanije glede sigurnosti plovidbe (čl. 175. st. 1. PZ). 
pravo služnosti, pravo zakupa ili neko drugo pravo iz kojeg izvodi pravo na korištenje zemljišne čestice, odnosno pomorskog ili vodnog dobra' (čl. 118. st. 3. t. 3. ZR). Dakle, dozvola za istraživanje i eksploataciju ugljikovodika, odnosno sklopljeni ugovor sukladno odredbama ZIEU-a imat će za investitora, odnosno koncesionara značenje dokaza o postojanju pravnog interesa za izdavanje građevinske dozvole. Pored navedenoga, jedna od zakonom propisanih pretpostavki za izdavanje građevinske dozvole je i dostava dokaza o uplaćenom komunalnom i vodnom doprinosu te građevinskoj pristojbi prema posebnom zakonu (čl. 121. st. 2. ZR). Mogućnost primjene te odredbe, kao što će se vidjeti iz daljnjeg teksta, na odobalne objekte vrlo je upitna.

Naime, komunalni doprinosi su novčana javna davanja koja se, sukladno odredbama Zakona o komunalnom gospodarstvu, ${ }^{16}$ plaćaju za građenje i korištenje objekata i uređaja komunalne infrastrukture - javih površina, nerazvrstanih cesta, groblja i krematorija te javne rasvjete. Ti doprinosi predstavljaju prihod jedinice lokalne samouprave (dalje: JLS), a njihova naplata počiva na načelu ekvivalentnosti, odnosno zahtjevu da se teret financiranja za usluge i dobra koja se obveznicima pružaju raspodijeli sukladno koristima koje pojedini subjekti imaju od tih usluga. ${ }^{17}$ Zbog velike udaljenosti od obale (većina odobalnih objekata nalazi se na vanjskoj granici teritorijalnog mora Republike Hrvatske) vlasnici, odnosno korisnici odobalnih objekata se, u pravilu, ne koriste dobrima i uslugama za koje se komunalni doprinos naplaćuje zbog čega je upitno ostvarenje načela ekvivalentnosti, a time i samog ratia naplate komunalnog doprinosa. Iz navedenog se nameće pitanje zakonitosti naplate komunalnih doprinosa odobalnim objektima za istraživanje i eksploataciju ugljikovodika. Ukoliko bi naplata komunalnih doprinosa uopće bila zakonita, to otvara novo pitanje - pitanje na koji način odrediti JLS (ili odnos između više jedinica) koja ima pravo naplatiti komunalni doprinos, budući da njihove granice na moru nisu utvrđene niti je uspostavljen katastar pomorskog dobra na moru.

Predstavničko tijelo svake JLS donosi odluku o komunalnom doprinosu kojom se, između ostaloga, određuju zone u gradu, odnosno općini i jedinična vrijednost komunalnog doprinosa po vrsti objekta (čl. 23. st. 7. ZKG), a na temelju kojega se donose pojedinačna rješenja o komunalnom doprinosu. Budući da morski prostori u kojima se nalaze odobalni objekti za istraživanje i eksploataciju nisu u obuhvatu jedinica lokalne samouprave, JLS ta područja ne mogu obuhvatiti odlukom o komunalnom doprinosu, a ako nisu obuhvaćena odlukom, ne mogu niti donijeti rješenje. Može se zaključiti da

$16 \quad$ NN, br. 36/95, 109/95, 21/96, 70/97, 128/99, 57/00, 129/00, 59/01, 82/04, 110/04, 178/04, 38/09, 79/09, 153/09, 49/11, 84/11, 90/11, 144/12, 56/13, 94/13, 153/13, 147/14, 36/15 (u daljnjem tekstu: ZKG).

17 Žunić-Kovačević, N., Gadžo, S., Komunalna naknada u RH i njezino pozicioniranje u odnosu na teoretske i normativne koncepte financijskog prava, Zbornik Pravnog fakulteta Sveučilišta u Rijeci, v. 35, br. 1, (2014), str. 253. Autori načelo korisnosti navode kao konstitutivno obilježje svih korisničkih naknada (a što komunalni doprinos nesporno jest). Ovo je načelo vidljivo i iz obveze jedinice lokalne samouprave na razmjerni povrat sredstava ukoliko se ne realizira godišnji program gradnje objekata i uređaja komunalne infrastrukture. 
je odredba o komunalnom doprinosu iz ZR-a neprimjenjiva na odobalne objekte te da ovlaštenik dozvole neće moći dostaviti potvrdu o uplaćenom komunalnom doprinosu, što je uvjet za izdavanje građevinske dozvole.

Vodni su, pak, doprinosi vrsta vodnih naknada koji služe kao izvor sredstava za financiranje vodnog gospodarstva i prihod su Hrvatskih voda. ${ }^{18}$ Uredbom o visini vodnog doprinosa ${ }^{19}$ propisane su Zone za određivanje visine vodnog doprinosa. Od cjelokupnog morskog područja Republike Hrvatske Uredbom je obuhvaćeno jedino zaštićeno obalno područje, dakle, području mora u širini $300 \mathrm{~m}$ od obalne crte. ${ }^{20}$ Vodni se doprinosi, prema važećim pravilima, ne mogu naplatiti za građenje izvan toga pojasa, a odobalni objekti za istraživanje i eksploataciju nalaze se miljama daleko od obale pa je i odredba kojom je propisana obveza dostave dokaza o plaćenom vodnom doprinosu, kao pretpostavka za izdavanje građevinske dozvole, neprimjenjiva na te odobalne objekte.

Svrha naplate navedenih doprinosa jasna je kada se oni naplaćuju za gradnju rudarskih objekata i postorojenja na kopnu pa i u zaštićenom obalnom području, no čini se da je mogućnost primjene postojećih rješenja upitna u odnosu na odobalne objekte za istraživanje i eksploataciju ugljikovodika. Čini se da se i s tog aspekta potvrđuje tvrdnja da odobalni objekti za istraživanje i eksploataciju ugljikovodika iz podmorja ne bi smjeli biti podvrgnuti istim pravnim rješenjima kao oni na kopnu, odnosno da zaslužuju zasebnu regulaciju.

Osim što analizirane odredbe ne čine razliku između objekata za istraživanje i eksploataciju na kopnu od onih na moru, one nemaju niti obilježja posebnog stvarnopravnog uređenja za rudarske objekte i postrojenja što bi upućivalo na zaključak da se odobalni objekti za istraživanje i eksploataciju ugljikovodika tretiraju kao nekretnine, uz primjenu općeg stvarnopravnog režima. ${ }^{21}$

Na drukčiji zaključak, da su odobalni objekti pokretnine, upućuju odredbe Pravilnika o bitnim tehničkim zahtjevima, koji je donesen na temelju ranije važećeg

18 Čl. 4. i 5. te 6.-12. Zakona o financiranju vodnog gospodarstva, NN, br. 153/09, 90/11, 56/13, $154 / 14$.

19 NN, br. 78/10, 76/11, 19/12, 151/13. (vidjeti čl. 3. Uredbe).

20 Arg. ex čl. 49. st. 1. Zakona o prostornom uređenju i gradnji, NN, br. 76/07, 38/09, 55/11, 90/11, 50/12, 55/12, 80/13, 153/13, 78/15.

21 Pišući o posebnom pravnom uređenju za rudarske objekte i postrojenja (bez razlikovanja objekata na kopnu od objekata na moru), prema Zakonu o rudarstvu iz 2009. (a koji se u pogledu pravnog statusa tih objekata u bitnome ne razlikuje od važećeg ZR-a), Nikšić je došao do zaključka da proučavani zakoni 'ne sadrže pravila koja bi imala karakter posebnog stvarnopravnog uređenja za rudarske objekte i postrojenja' te da se na navedene objekte primjenjuju odredbe ZV-a. Nikšić, S., Posebno stvarnopravno uređenje za rudarske objekte i postrojenja, u: Gavella, N. et alt., Stvarno pravo - Posebna pravna uređenja, svezak treći, Narodne novine, Zagreb, 2011., str. 547-548. Dalje Nikšić razrađuje modalitete razdvajanja prava vlasništva na zemljištu od prava vlasništva na objektima i postrojenjima, ali samo u odnosu na takve objekte na kopnu. Ibid., str. 548-551. Ovi modaliteti, naravno, nisu primjenjivi na razdvajanje prava vlasništva na objektima i postrojenjima od pomorskog dobra koje je opće dobro, o čemu opširnije infra 2.2.2. 
Zakona o rudarstvu. U čl. 4. Pravilnika propisano je da se rudarski radovi u podmorju Republike Hrvatske izvode s platforme i/ili plovnog objekta za bušenje. Njime je propisano i da su platforme, prema pomorskim propisima, tehnički plovni objekti (pokretni odobalni objekt namijenjen za istraživanje i eksploataciju podmorja) i/ili nepomični odobalni objekt (nepokretni objekt namijenjen za istraživanje i eksploataciju) (čl. 3. st. 1. Pravilnika).

\subsection{Pravni status odobalnih objekata prema Pomorskom zakoniku}

Odredbe Pravilnika nameću potrebu ispitivanja pravnog statusa 'platformi' i 'plovnog objekta za bušenje' prema pomorskim propisima, u prvom redu prema Pomorskom zakoniku. Ta bi potreba za konzultiranjem odredaba PZ-a postojala i bez Pravilnika, već zbog same činjenice da se ta djelatnost obavlja na moru. Terminološki je Pravilnik djelomično usklađen s odredbama PZ-a. Naime, PZ razlikuje tri vrste pomorskih objekata - plovne objekte, plutajuće objekte i nepomične odobalne objekte (čl. 5. st. 1. t. 2. PZ). Plovni su objekti namijenjeni plovidbi morem, a kao posebna vrsta plovnog objekta naveden je tehnički plovni objekt. Prema zakonskoj definiciji tehički plovni objekt je brod, sa ili bez mehaničkog poriva koji je namijenjen za obavljanje tehničkih radova, pri čemu je kao jedan od primjera naveden upravo pokretni odobalni objekt namijenjen za istraživanje i eksploataciju podmorja (čl. 5. st. 1. t. 12. PZ). Usporede li se odredbe Pravilnika i PZ-a, u kategoriju tehičkog plovnog objekta prema PZ-u ulazile bi dvije vrste objekata za obavljanje rudarskih radova u podmorju iz Pravilnika - plovni objekti za bušenje (tzv. drilling ships) i one platforme koje su pokretni odobalni objekti za istraživanje i eksploataciju. Druga kategorija pomorskih objekata prema PZ-u su plutajući objekti. Oni nisu namijenjeni plovidbi, već su stalno privezani ili usidreni na moru. U Zakoniku su navedeni i primjeri za te objekte - plutajući dok, plutajuće skladište, plutajući restoran, plutajuća elektrana, pontonski most, pontonska marina. Taj popis nije taksativan, već primjeričan pa se nameće pitanje bi li neki objekt za istraživanje i eksploataciju podmorja, ukoliko udovoljava zakonskoj definiciji, mogao biti podveden pod tu kategoriju. Primjerice, da li je poluuronjiva platforma, koja se na mjestu na kojem obavlja istraživanje ili eksploataciju usidrena, a održava se na površini vlastitim uzgonom, plutajući objekt? Nejasna je, naime, razlika između tehničkog plovnog objekta bez mehaničkog poriva i plutajućeg objekta. Ako je razlika između plutajućih objekata i tehničkih plovnih objekata bez mehaničkog poriva upravo u njihovoj namjeni (a koja je određena samo za tehničke plovne objekte, dok je iz popisa plutajućih objekata vidljivo da niti jedan ne služi obavljanju tehničkih radova te je moguće zaključiti da se radi o objektima koji se na jednom mjestu stacioniraju i namijenjeni su, u pravilu, da tamo trajnije ostanu) onda bi se poluuronjive platforme trebalo držati tehničkim plovnim objektima, dakle, brodovima. Ako je ta pretpostavka točna, niti jedan objekt za istraživanje i eksploataciju ugljikovodika, u užem smislu, neće biti plutajući objekt. Takav bi zaključak proizlazio i iz Pravilnika. Treća vrsta 
pomorskih objekata prema PZ-u su nepomični odobalni objekti koji su u potpunosti ili djelomično ukopani u morsko dno ili položeni na morsko dno, a koji nisu namijenjeni za plovidbu. Kao primjer te posljednje skupine pomorskih objekata naveden je nepomični odobalni objekt za istraživanje i eksploataciju podmorja (čl. 5. st. 1. t. 14 PZ), što odgovara i terminologiji iz Pravilnika. U tu kategoriju ulaze tzv. jack-up platforme.

Navedene kategorije pomorskih objekata nisu podvrgnute istim pravnim normama i imaju različit pravni status. Odredbe PZ-a o brodovima primjenjuju se na druge pomorske objekte (osim jahti) samo ako je to Zakonikom izričito propisano (čl. 2. st. 2. PZ-a). Jedna od odredaba za koju nije izrijekom propisano da se primjenjuje na ostale pomorske objekte je upravo odredba čl. 208 PZ-a kojom je propisano da je brod (a time i tehnički plovni objekt) pokretna stvar. Okolnost da se ta odredba ne primjenjuje na plutajuće i nepomične odobalne objekte, ne znači nužno da oni nisu pokretnine, ali daje prostora za razmišljanje u tom smjeru. To posebice u odnosu na nepomične odobalne objekte (čiji bi naziv, također, upućivao na takav zaključak) ukoliko se ima na umu da na takvu kvalifikaciju upućuju i ranije razmatrane odredbe ZR-a. Odgovarajuća primjena odredaba PZ-a o brodovima na nepomične odobalne objekte propisana je za Glavu III. Dijela V. PZ-a, kojom je uređen postupak upisivanja u upisnik brodova. Struktura upisnika, koja je ista kao i za brod, mogla bi svakako biti argument $u$ korist tvrdnje da se radi o pokretnim objektima. ${ }^{22}$ Odgovarajuća primjena odredaba o sposobnosti broda za plovidbu propisana je i u odnosu na utvrđivanje sposobnosti nepomičnog odobalnog objekta za uporabu (čl. 103. st. 1. PZ), a koji postupak i za brodove i za nepomične odobalne objekte provodi Hrvatski registar brodova. I odredbe MARPOLA, implementirane u PZ, primjenjuju se na sve plovne objekte, uključujući pričvršćene i ploveće platforme za bušenje podmorja i istraživanje i eksploataciju nafte. ${ }^{23} \mathrm{Me}-$ đutim, time što su nepomični odobalni objekti za istraživanje i eksploataciju ugljikovodika predmet reguliranja pomorskog upravnog prava nikako ne znači da se na njih primjenjuju imovinsko pravni propisi pomorskog prava. ${ }^{24}$ Štoviše, u nedostatku izričitog normativnog uređenja njihova pravnog statusa unutar posebnih propisa - PZ-a, ZIEU-a i ZR-a te nemogućnosti odgovarajuće primjene odredaba koje se odnose na brod, pravni osnov za pravnu kvalifikaciju treba potražiti u općem propisu - Zakonu o vlasništvu, kojim su propisani posebni kriteriji za razlikovanje pokretnina od nekretnina. ${ }^{25}$

Konačno, treba navesti i to da je jedini propis koji sadrži definiciju odobalnog objekata Zakon o sigurnosti pri odobalnom istraživanju i eksploataciji ugljikovodika. Međutim, navedeni propis odobalnim objektom smatra nepomičan ili pomičan objekt s povezanom infrastrukturom koji se koristi za odobalno istraživanje i eksploataciju ugljikovodika i/ili u svezi s tim (u čl. 4. st. 1. t. 18.), čime ne razrješava dvojbu u odnosu na pitanje je li takav objekt pokretnina ili nekretnina.

22 Upis u upisnik nepomičnih odobalnih objekata ipak (za razliku od upisa brodova) ne proizvodi učinak stjecanja hrvatske državne pripadnosti.

23 Vidjeti čl. 2. st. 1.t. 4. MARPOL-a.

24 U tom smislu vidjeti: Grabovac, I., op. cit. (bilj. 9), str. 39.

25 Vidjeti infra 2.2.2. 
Analiza odredaba ZIEU-a, ZR-a i PZ-a pokazala je da pravni status odobalnih objekata za istraživanje i eksploataciju ugljikovodika nije riješen sustavno, već su neki odobalni objekti po svojim karakteristikama tehnički plovni objekti - brodovi, dok je u odnosu na druge, nepomične odobalne objekte jasno da nisu brodovi i da se na njih ne primjenjuju odredbe PZ-a o brodovima, ali je ostalo dvojbeno jesu li pokretnine ili nekretnine. ${ }^{26}$

U nastavku rada će se ukratko izložiti pravne posljedice različite pravne kvalifikacije odobalnih objekata za istraživanje i eksploataciju ugljikovodika iz Jadrana i upozoriti na rješenja koja nisu prihvatljiva i zahtijevaju izmjenu.

\subsubsection{Posebno o pravnom statusu tehničkih plovnih objekata namijenjenih za istraživanje i eksploataciju ugljikovodika}

Pokretni odobalni objekt za istraživanje i eksploataciju podmorja je, kao i plovni objekt za bušenje (tzv. drilling ship), tehnički plovni objekt, dakle, vrsta broda. ${ }^{27}$ Iako tehničkim plovnim objektima primarna namjena nije plovidba (a brodovima u užem smislu riječi jest, arg. ex. čl. 5. st. 1. t. 4. PZ-a), Pomorski je zakonik prihvatio širu definiciju broda pod koju je podveo i tehnički plovni objekt kao objekt sa ili bez mehaničkog poriva koji je namijenjen za obavljanje tehničkih radova. ${ }^{28}$

Izrijekom je, Pomorskim zakonikom, propisano da je brod (a time i tehnički plovni objekt) pokretna stvar i da na njemu mogu postojati stvarna prava, u prvom redu pravo vlasništva, hipoteka na brodu i pomorski privilegij. Za sve je brodove uspostavljen registarski sustav u kojem se evidentiraju brodovi i stvarna prava na njima. ${ }^{29},{ }^{30}$

26 Detaljnije o tome vidjeti infra 2.2.2.

27 U talijanskoj literaturi postoji konsenzus oko toga da su bušaći brodovi - brodovi, međutim, u odnosu na druge objekte za istraživanje i eksploataciju postoji čitava lepeza različitih shvaćanja. Za vrlo detaljan prikaz talijanske doktrine vidjeti: Orru, E., La configurazione giuridica delle piattaforme e degli impianti off-shore alla luce delle nuove esigenze in materia di sigurezza in mare, u: Trattato breve di diritto marittimo, Volume I: Pincìpi - Soggetti - Beni - Attività, (coordinato da Antonini, A.), Giuffrè Editore, 2007., str. 341-342. i tamo citirana literatura.

28 Grabovac, I., Petrinović, R., Pomorsko pravo: pomorsko javno, upravno i radno pravo, Pomorski fakultet u Splitu, Split, 2006., str. 102.

29 O registrima plovnih objekata, kao i razlozima uvođenja registarskog sustava, vidjeti: MARIN, J., Registri plovnih objekta i zrakoplova, u: Hrvatsko registarsko pravo - registri pravnih osoba, nekretnina, pokretnina i prava (opća redakcija: JOSIPOVIĆ, T.), Narodne novine, Zagreb, 2006., str. 119-142. id., Brodovi i plovila unutarnje plovidbe, u: GAVELLA, N., ...[et al.], Stvarno pravo - posebna pravna uređenja (redaktor: GAVELLA, N.), Narodne novine, Zagreb, 2011., str. 633-651. Pavić čak smatra da su brodovi, budući da su u pogledu stjecanja, prijenosa i gubitka stvarnih prava podvrgnuti knjižnom režimu u tom pogledu izjednačeni s nekretninama. PAVIĆ, D., Pomorsko imovinsko pravo, Književni krug Split, Split, 2006., str. 39. Ipak, treba naglasiti da se radi o sustavima s brojnim razlikama i specifičnostima.

30 Za pomorske brodove postoje tri vrste upisnika - za trgovače brodove, za ribarske brodove i za javne brodove pa ostaje nejasno u koji se upisnik upisuju tehnički plovni objekti. 
Posebnim je odredbama PZ-a uređena izvanugovorna odgovornost vlasnika broda i brodara za štetu koju brod prouzroči osobama i stvarima izvan broda te okolišu (Dio VIII, Glava IV, čl. 808-823.f). Pitanje je, međutim jesu li navedene odredbe PZ-a uopće primjenjive na štete koje bi iz izvanugovornih odnosa prouzročili odobalni objekti za istraživanje i eksploataciju ugljikovodika iz podmorja. Zakonik, naime, sadrži, po uzoru na međunarodne instrumente, ${ }^{31}$ posebne odredbe za slučaj onečišćenja mora uljem koje se prevozi kao teret (čl. 813.-823. PZ) te za onečišćenje mora pogonskim uljem (čl. 823.a-823.f PZ). Već iz samog naziva prvog sustava odgovornosti - odgovornosti za onečišćenje mora uljem koje se prevozi kao teret proizlazi da on neće biti primjenjiv na tehničke plovne objekte, dok će se odredbe o odgovornosti za onečišćenje mora pogonskim uljem moći primijeniti samo iznimno, u pravilu za štetu nastalu u fazi transporta, odnosno za onečišćenje pogonskim gorivom (dakle, na objekte na vlastiti pogon). Slučajevi izlijevanja nafte iz bušotina nisu obuhvaćeni navedenim sustavima. Ostaje još mogućnost primjene opće odredbe čl. 812. PZ-a koja se odnosi na odgovornost za onečišćenje mora koje brod prouzroči 'izlijevanjem ili izbacivanjem tvari opasnih i štetnih za okoliš’ i prema kojoj brod odgovara prema načelu stroge objektivne odgovornosti. Dvojbeno je, međutim, bi li se izlijevanje nafte iz bušotina moglo smatrati štetom koju 'prouzroči brod izlijevanjem ili izbacivanjem tvari opasnih i štetnih za okoliš’ iz čl. 812. PZ-a. Ukoliko to ne bi bilo moguće, slijedeće pitanje koje se nameće jest bi li sud prilikom odlučivanja o tako nastaloj šteti trebao eventualnu prazninu nadopuniti analognom primjenom upravo te odredbe, budući da je PZ-om cjelovito uređena materija izvanugovorne odgovornosti brodara, ili primjenom općih pravila građanskog prava o izvanugovornoj odgovornosti za štetu.

Vezano uz pitanje izvanugovorne odgovornosti za štetu nameće se i pitanje mogućnosti primjene instituta ograničenja te odgovornosti. Naime, specifičnost je pomorskog prava postojanje instituta ograničene odgovornosti brodara, odnosno brodovlasnika, koji je povijesno formiran radi uspostave ravnoteže u snošenju rizika između subjekata involviranih u pomorsko poduzetništvo, a kasnije zadržan posebice iz razloga što se njime rizik plovidbenog posla činio osigurljivim. ${ }^{32}$ Upravo taj argument, osigurljivosti rizika, jedini je koji bi bio prihvatljiv za primjenu tog instituta na područje istraživanja i eksploatacije ugljikovodika iz podmorja. Problem, međutim, predstavlja određivanje visine te odgovornosti. ${ }^{33}$ Primjena općeg sustava ograničenja odgovornosti, kod kojeg

31 Konvencija o građanskoj odgovornosti za onečišćenje mora uljem iz 1992. (Civil Liability Convention - CLC) i Konvencija o građanskoj odgovornosti za onečišćenje mora pogonskim uljem iz 2001. (Bunker Convention), NN-MU, br. 9/06.

32 O ograničenju odgovornosti brodara vidjeti primjerice: Pavić, D., op. cit. (bilj. 27), str. 70-83.

33 Osnovu za izračun ograničenja brodareve odgovornosti u pozitivnom hrvatskom pravu (koje na napisano po uzoru i radi usklađenja s Međunarodnom konvencijom o ograničenju odgovornosti za pomorske tražbine iz 1976.), čini skala sastavljena od više grupa, odnosno slojeva ograničenja odgovornosti prema tonaži broda. Granice odgovornosti za tražbine koje su proizašle iz jednoga istog događaja iznose u pogledu tražbina zbog smrti ili tjelesnih ozljeda 2 milijuna SDR-a za brod s tonažom koja ne prekoračuje 2.000 tona, a u pogledu ostalih tražbina 
je kriterij za određivanje visine odgovornosti tonaža broda, apsolutno je neprihvatljiva i neprimjenjiva na odobalne objekte za istraživanje i eksploataciju ugljikovodika ako se ima $u$ vidu $-\mathrm{s}$ jedne strane nesrazmjer između tonaže platforme ${ }^{34}$ i njezine vrijednosti te još više ukoliko se uzme u obzir razmjere šteta koje mogu nastati kao posljedica erupcije, požara, gubitka kontrole nad bušotinom i sl. Iz navedenih je razloga i ranije navedena Konvencija o ograničenju odgovornosti iz 1976. u čl. 19. st. 2. isključila pokretne platforme iz područja svoje primjene, a to čini i Pomorski zakonik kojim je propisano da se dio Zakonika kojim je regulirano ograničenje odgovornosti ne primjenjuje na 'ploveće platforme koje se koriste za istraživanja i iskorištavanje prirodnih bogatstava morskog dna i podzemlja' (čl. 399. st. 2. PZ). Međutim, navedenom se odredbom isključuje mogućnost pozivanja na ograničenje odgovornosti za štete nastale samo s onih 'pokretnih odobalnih objekata za istraživanje i eksploataciju podmorja' koji su platforme. Čini se da se bušaći brod ne bi mogao podvesti pod pojam ploveća platforma (to bi proizlazilo iz samog naziva, ali i iz Pravilnika o bitnim tehničkim zahtjevima kojim je propisano da se rudarski radovi u podmorju izvode s platforme i/ ili plovnog objekta za bušenje, čl. 4.). Vlasnik takvog broda mogao bi se pozvati na opće ograničenje odgovornosti prema odredbama PZ-a. ${ }^{35}$

\subsubsection{Posebno o pravnom statusu nepomičnih odobalnih objekata}

Nepomični odobalni objekt je pomorski objekt u potpunosti ili djelomično ukopan u morsko dno ili položen na morsko dno, koji nije namijenjen za plovidbu (npr. nepomični odobalni objekt za istraživanje i eksploataciju podmorja...) (čl. 5. st. 1. t. 14. PZ). Nesporno je da ti objekti nisu brodovi. Zakonik, međutim, ne sadrži odredbe o pravnom statusu nepomičnih odobalnih objekata, pa se može postaviti pitanje jesu

1 milijun SDR-a za brod s tonažom koja ne prekoračuje 2.000 tona, dok se na brodove koji prekoračuju ovu tonažu izračunavaju dodaci prema odredbi čl. 391 PZ-a. 8. lipnja 2015. godine na snagu su stupili novi iznosi ograničenja odgovornosti u skladu s postupkom prešutnog prihvata (za smrt i tjelesne ozljede 3,02 milijuna SDR-a, a za ostale tražbine 1,51 milijun). Aktualna vrijednost 1 SDR-a (obračunska jedinica koju utvrđuje MMF) na dan 15. listopada 2015. iznosi $1 \mathrm{SDR}=1,2395 €$, odnosno 1,4179 \$. Vidjeti: https://www.imf.org/ external/np/fin/ data/rms_mth.aspx?SelectDate=2015-10-31\&reportType=CVSDR Mrežna stranica posjećena 15. listopada 2015.

34 Baždarenje se obavlja u skladu s Pravilima za statutarnu certifikaciju pomorskih objekata, baždarenja, NN, br. 97/2015., a koja u odnosu na tehničke plovne objekte ne propisuju ništa posebno, osim da se takvim objektima utvrđuje samo bruto tonaža (3.1.2.), prema formuli danoj za izračun bruto tonaže broda većeg od 24 metra koji obavlja međunarodnu plovidbu.

35 U norveškom je Pomorskom zakoniku propisano da bušaće platforme i slične mobilne konstrukcije koje se ne smatraju brodovima odgovaraju, neovisno o veličini konstrukcije do 36 milijuna SDR-a u pogledu tražbina zbog smrti ili tjelesnih ozljeda, a 60 milijuna SDR-a u pogledu ostalih tražbina. Pored toga, Norway Act 29 November 1996 No 72 relating to Petroleum Activities propisuje objektivnu i neograničenu odgovornost operatera djelatnosti istraživanja i eksploatacije za onečišćenje okoliša (Poglavlje 7), dok je posebno pravo na naknadu propisano i za norveške ribare (Poglavlje 8). Tekst na engleskom dostupan je na Internet stranici http://www.npd.no/en/ Regulations/Acts/Petroleum-activities-act/\#10-9. Mrežna stranica posjećena 12. listopada 2015. 
li ti objekti nekretnine, na što bi upućivao i njihov naziv ili su pokretnine. Naime, za brodove je Zakonikom izrijekom propisano u čl. 208. PZ-a da su pokretne stvari, dok za nepokretne odobalne objekte nije propisano ništa. Stoga je za njihovu kvalifikaciju kao pokretnine ili nekretnine potrebno konzultirati odredbe općeg propisa - Zakona o vlasništvu.

Osnovni kriterij za razlikovanje pokretnih od nepokretnih stvari je prirodni kriterij ili kriterij prirodne kakvoće. U smislu odredaba ZV-a nekretninom se smatra čestica zemljine površine zajedno sa svime što je sa zemljištem trajno spojeno na površini ili ispod nje, dakle, stvari koje ne mogu mijenjati položaj u prostoru bez da im se pritom uništi bit ili promjeni dosadašnja struktura, dok se pokretninom smatra stvar koja se može premjestiti s jednog mjesta na drugo, a da joj se ne povrijedi bit (čl. 2. st. 3. i 4. ZV-a). Što je na površini zemlje, iznad ili ispod nje izgrađeno, a namijenjeno je da tamo trajno ostane, ili je u nekretninu ugrađeno, njoj dograđeno, na njoj nadograđeno ili bilo kako drukčije s njom trajno spojeno, dio je te nekretnine sve dok se od nje ne odvoji, ali nije dio zemljišta ono što je s njime spojeno radi neke prolazne namjene (čl. 9. st. 3. ZV). ${ }^{36}$ Trajna veza stvari spojenih sa zemljištem (u tom slučaju morskim dnom) pravna je pretpostavka za pravno jedinstvo nekretnine. ${ }^{37}$

Za odgovor na pitanje jesu li nepomični odobalni objekti pokretnine ili prirast zemljišta bitno je odgovoriti na pitanje jesu li oni u morsko dno ukopani ili na morsko dno položeni radi trajne ili prolazne namjene. Sintagme ‘trajno spojeno' i 'prolazna namjena' nisu u sudskoj praksi i pravnoj doktrini dobile tumačenje na temelju kojega bi se, sa sigurnošću, moglo tvrditi u kojem slučaju takva veza postoji, odnosno ne postoji, što bi u slučaju spora sasvim sigurno dozvoljavalo argumente za jednu i drugu tezu. Za platforme instalirane radi istraživanja ugljikovodika, koje u pravilu traje pet godina, jasno je da se ne radi o trajnoj vezi, već da se one postavljaju radi prolazne namjene - vremenski ograničenog istraživanja. U odnosu na odobalne objekte za eksploataciju koji se postavljaju na vremensko razdoblje od 25 ili više godina moglo bi se braniti tezu da se radi o trajnoj vezi s morskim dnom, odnosno zemljištem. Činjenica je, s druge strane, da će ti objekti biti na određenom mjestu dok postoji komercijalna isplativost za eksploataciju, a najdulje na vrijeme utvrđeno dozvolom, što odnosu između zemljišta i odobalnog objekta, ma kako dugo ono bilo, daje obilježje privremenosti.

Drugi kriterij za određivanje je li neka stvar pokretna ili nepokretna je kriterij pertinencije prema kojemu se stvari koje su po svojoj naravi pokretne smatraju u pravnom smislu nepokretnima ako su pripadak nepokretne stvari (čl. 2. st. 4. ZV-a). Da bi neka pokretna stvar mogla biti pertinencijom određene nekretnine, potrebno je da budu zadovoljene pretpostavke iz čl. 7. st. 1. ZV-a, odnosno da je vlasnik tu

36 Talijanski je zakonodavac nekretninom smatra i plutajuće objekte (edifici galleggianti) na siguran način pričvršćene za obalu ili riječno korito (riva o alveo) namijenjeni da tamo trajno ostanu. (Art. 812/2 Codice civile).

37 O pravnom jedinstvu nekretnine vidjeti primjerice: Simonetti, P., Nekretnine kao objekti prava vlasništva i prava građenja, Zbornik Pravnog fakulteta u Rijeci, vol. 30, br. 1, (2009), str. 33-62. 
pokretnu stvar namijenio da kao sporedna trajno služi svrsi glavne stvari te da stoji u takvom prostornom odnosu prema glavnoj stvari koji odgovara toj namjeni. Zakonom je propisana i predmnijeva o tomu da su namijenjeni da trajno služe svrsi glavne stvari (između ostaloga) i strojevi i slični uređaji namijenjeni toj djelatnosti (čl. 7. st. 4. ZV).

Ukoliko se primjenom navedenih kriterija određenu stvar (nepomični odobalni objekt) ne bi moglo definirati kao pokretnu ili nepokretnu, treba primijeniti odredbu čl. 2. st. 7. ZV-a kojom je propisano da se u sumnji je li što pokretna ili nepokretna stvar smatra da je pokretna.

Primjenom navedenih kriterija na nepokretne odobalne objekte koji služe za istraživanje može se zaključiti da su oni zbog svoje prolazne namjene, odnosno vremenski ograničene vezanosti za morsko dno (neovisno o njihovoj čvrstoj vezanosti) pokretnine. To tim više uzme li se u obzir treći kriterij - da se u sumnji je li nešto pokretnina ili nekretnina, stvar ima smatrati pokretninom. Međutim, u odnosu na nepokretne odobalne objekte za eksploataciju, zbog relativno dugog vremenskog trajanja eksploatacije, niti opći propis zapravo ne daje konačan odgovor u odnosu na njihovu kvalifikaciju kao pokretnina i/ili nekretnina.

Analiza odredaba PZ-a i kriterija za utvrđivanje pokretnosti/nepokretnosti određene stvari iz ZV-a dovela je do zaključka da je moguće da se neće nužno tretirati na isti način svi nepomični odobalni objekti za istraživanje i eksploataciju ugljikovodika. Nepomične odobalne objekte za istraživanje treba, zbog njihove prolazne namjene, odnosno vremenski ograničene vezanosti za morsko dno, tretirati kao pokretnine. Međutim, u odnosu na nepomične odobalne objekte za eksploataciju niti opći propis nije pružio konačan odgovor u odnosu na njihovu kvalifikaciju kao pokretnina ili nekretnina, što je zbog trajnosti njihove veze s morskim dnom ustalo upitno. Stoga će se u nastavku rada posebna pažnja obratiti upravo na te odobalne objekte i moguće pravne posljedice njihova tretiranja kao nekretnina.

Odgovor na pitanje jesu li ‘nepomični odobalni objekti za eksploataciju’ pokretnine ili nekretnine posebice bi mogao biti važan u slučaju kada su takvi objekti postavljeni unutar područja unutarnjih morskih voda i teritorijalnog mora, budući da je morsko dno i podzemlje u tom području dio pomorskog dobra, dakle opće dobro. ${ }^{38},{ }^{39}$ To stoga što se građevine i drugi objekti na pomorskom dobru koji su s njime trajno povezani smatraju pripadnošću pomorskog dobra (čl. 5. st. 1. ZPDML). Tim je odredbama za

$\overline{38}$ Pomorsko dobro čine unutarnje morske vode i teritorijalno more, njihovo dno i podzemlje, te dio kopna koji je po svojoj prirodi namijenjen općoj upotrebi ili je proglašen takvim, kao i sve što je s tim dijelom kopna trajno spojeno na površini ili ispod nje. (čl. 3. st. 2. Zakona o pomorskom dobru i morskim lukama, NN, br. 158/03, 100/04, 141/06, 38/09, 123/11 (u daljnjem tekstu: ZPDML)).

39 Može se istaknuti, međutim, da je da je ZIEU posebni zakon u odnosu na ZPDML, kao i to da je čl. 5. st. 1. ZIEU-a propisano da su rezerve ugljikovodika u ležištima koja se nalaze unutar područja kopna, mora i/ili podzemlja nad i u kojima Republika Hrvatska ima suverenitet, jurisdikciju i/ili suverena prava isključivo vlasništvo Republike Hrvatske. Tom je odredbom propisana iznimka od načela superficies solo cedit i pravno su odvojene rezerve ugljikovodika od zemljišta. 
područje pomorskog dobra impostirano i potvrđeno načelo općeg stvarnopravnog režima - načelo superficies solo cedit. Izričito je zabranjeno stjecanje prava vlasništva i drugih stvarnih prava na pomorskom dobru po bilo kojoj osnovi (čl. 5. st. 2. ZPDML). ${ }^{40}$

Istraživanje i eksploatacija ugljikovodika, kao specifično gospodarsko korištenje pomorskog dobra, moći će se obavljati samo uz gradnju novih građevina i drugih objekata na pomorskom dobru, platformi. U slučaju da se utvrdi kako se radi o objektu koji je u skladu s ranije objašnjenim načelom superficies solo cedit dio nekretnine, biti će potrebno iznaći moduse kojima se njihov pravni status razdvaja i time omogućava koncesionaru biti vlasnikom platforme. ZPDML ne predviđa takvo rješenje. Štoviše, upravo zbog navedene zabrane stjecanja prava vlasništva i drugih stvarnih prava na pomorskom dobru u pravnoj doktrini prevladava stav da takvo odvajanje nije moguće. ${ }^{41}$

Moguće konstrukcije pravnog odvajanja pravnog statusa nepomičnih odobalnih objekata za eksploataciju ugljikovodika od pomorskog dobra treba potražiti u općem propisu - Zakonu o vlasništvu. ZV, kojim je načelo superficies solo cedit impostirano kao jedno od osnovnih načela stvarnih prava, poznaje nekoliko mogućih iznimaka od njegove primjene. Prva iznimka propisana je u odnosu na one zgrade i druge građevine koje su trajno povezane sa zemljištem ako ih od njega odvaja stvarno pravo koje svoga nositelja ovlašćuje da na tom tuđem zemljištu ima takvu zgradu ili drugu građevinu u svom vlasništvu (čl. 9. st. 4. ZV). ${ }^{42}$ Zbog ranije navedene izričite zabrane stjecanja stvarnih prava na pomorskom dobru iz ZPDML-a pravno odvajanje građevina i drugih objekta od pomorskog dobra neće biti moguće na temelju stvarnog prava. Druga mogućnost koja je propisana ZV-om odnosi se na zgrade i druge građevine koje od zemljišta ili od općeg dobra pravno odvaja na zakonu osnovana koncesija koja svojeg nositelja ovlašćuje da na tome ima takvu zgradu ili drugu građevinu u svome vlasništvu (čl. 9. st. 4. ZV). ${ }^{43}$

$\overline{40}$ Za vrlo iscrpan povijesni i pozitivnopravni prikaz problema stvarnih prava na pomorskom dobru vidjeti: Bolanča, D., Problem stvarnih prava na pomorskom dobru (bitne novine hrvatskog pomorskog zakonodavstva), PPP, god. 54 (2015), str. 327-358.

41 U pravnoj doktrini prevladava shvaćanje da je stupanjem na snagu ZPDML-a, koji je lex specialis i lex posterior u odnosu na $\mathrm{ZV}$, isključena mogućnost primjene navedene odredbe. Tako: Bolanča, D., Pomorsko dobro u svjetlu novog Zakona o pomorskom dobru i morskim lukama, Pravo i porezi, br. 2/04, str. 35. id., Problem..., op. cit. (bilj. 38), str. 347.; Frković, S., Stečena prava na pomorskom dobru, Nekretnine kao objekti imovinskih prava, Narodne novine, Zagreb, 2004., str. 147; Skorup, V., Vlasničkopravni aspekti pomorskog dobra, http://www.pomorskodobro.com /fokus-vlado-skorup.html Mrežna stranica posjećena 10. listopada 2015.

42 Stvarna prava na temelju kojih je moguće takvo odvajanje su pravo građenja i pravo stvarne služnosti koje svojeg ovlaštenika ovlašćuje imati građevinu na tuđoj nekretnini.

43 Rijetki su oni autori koji drže da i dalje ima prostora za tumačenje da postoji mogućnost za odvajanje zgrada i drugih građevina od pomorskog dobra, a takvo tumačenje temelje na tvrdnji da ZPDML nigdje izričito ne zabranjuje pravno odvajanje zemljišta od građevine. Tako: Josipović, T., Posebna pravna uređenja koncesija na nekretninama, Nekretnine kao objekti imovinskih prava, Narodne novine, Zagreb, 2004., str. 102; Tuhtan Grgić, I., Pravo vlasništva na objektima izgrađenima na pomorskom dobru, Zbornik radova Pomorsko dobro u fokusu znanosti i pragme (ur. Panjković, Ž.,) Rijeka, 2005., str. 140. 
ZPDML zabranjuje stjecanje stvarnih prava na pomorskom dobru, ali nigdje ne zabranjuje pravno odvajanje građevina i drugih objekata na temelju koncesije, odnosno mogućnost da pomorsko dobro ostane opće dobro, izvan vlasničkog režima, a da zgrade i druge građevine (u ovom slučaju odobalni objekti za istraživanje i eksploataciju) na temelju koncesije budu u vlasništvu koncesionara. ZPDML-om je propisano da se građevine i drugi objekti koji su trajno povezani s pomorskim dobrom 'smatraju' pripadnošću pomorskog dobra. Takva stipulacija ukazuje da je, kao i prema općem stvarnopravnom uređenju načelo superficies solo cedit samo oboriva predmnijeva, a jedina moguća pravna osnova obaranja ove predmnijeve i razdvajanja zgrade od općeg dobra jest upravo koncesija. ${ }^{44}$ Time se, naravno, ne dira u pravni status podmorja kao pomorskog, odnosno općeg dobra koji ostaje u nevlasničkom režimu. ${ }^{45}$

Doduše, tijekom faze istraživanja investitor prema odredbama ZIEU-a nije koncesionar pa ne bi imao pravnu osnovu za razdvajanje odobalnih objekata od zemljišta, ali to neće niti biti potrebno budući da su objekti koji se postavljaju tijekom faze istraživanja uvijek pokretnine zbog nepostojanja trajne veze sa zemljištem. ${ }^{46}$ Ovlaštenik dozvole stječe status koncesionara tek ukoliko se ispune zakonom propisane pretpostavke za izravnu dodjelu koncesije za eksploataciju pa bi od tog trenutka mogao imati i pravni temelj za to razdvajanje. Neprihvatljivo bi bilo da ovlaštenik dozvole, odnosno investitor dopremi svoje odobalne objekte za istraživanje i eksploataciju (koji su u registru nepomičnih odobalnih objekata upisani kao njegovo vlasništvo) i da ex lege dođe do izvlaštenja zbog njihove trajne povezanosti s morskim dnom. Osim toga,

U pravnoj se doktrini, međutim, često ukazuje na potrebu da se ZPDML uskladi s odredbama ZV-a. Vidjeti primjerice tekst Portal predlaže - Stjecanje vlasništva na zgradama ili drugim građevinama na temelju koncesije. http://www.pomorskodobro.com/prijedlozi /249-portal-predlaze-stjecanje-vlasnistva-koncesije.html Mrežna stranica posjećena 20. listopada 2015. Također vidjeti: Bolanča, D., Problem..., op. cit. (bilj. 38), str. 350-357.

44 Čl. 3. st. 4. ZV-a glasi: "Pravno nisu dijelovi općeg dobra one zgrade i druge građevine koje su na njemu izgrađene na temelju koncesije, pa one tvore zasebnu nekretninu dok koncesija traje". Čl. 9. st. 4. ZV-a glasi: "Nisu dijelovi zemljišta one zgrade i druge građevine koje su trajno povezane s tim zemljištem ako ih od njega pravno odvaja stvarno pravo koje svojega nositelja ovlašćuje da na tom tuđem zemljištu ima takvu zgradu ili građevinu u svome vlasništvu; isto na odgovarajući način vrijedi i za zgrade ili druge građevine koje od zemljišta ili od općeg dobra odvaja na zakonu osnovana koncesija koja svojeg nositelja ovlašćuje da na tome ima takvu zgradu ili građevinu u svome vlasništvu."

45 Vidjeti primjerice: Marin, J., Koncesija i pravo vlasništva na objektima izgrađenima na pomorskom dobru, Pravo u gospodarstvu, vol. 37, 1998, str. 246.-257.; Tuhtan, I., Pravno razdvajanje zgrada i drugih građevina od pomorskog dobra, Zbornik Pravnog fakulteta Sveučilišta u Rijeci, vol. 23, br. 1, (2002), str. 335-352.

46 Odredbom čl. 21. st. 4. ZIEU propisano je da se investitor obvezuje da će nakon donošenja odluke o odabiru, a prije izvođenja rudarskih radova, u slučaju potrebe za izdavanjem posebnih prethodnih suglasnosti i/ili dozvola od strane nadležnih tijela RH neophodnih za nesmetano korištenje zemljišta i/ili podzemlja unutarnjih morskih voda ili teritorijalnog mora $\mathrm{RH}$, odnosno podzemlja epikontinentalnog pojasa Jadranskog mora, u svrhu izvođenja rudarskih radova, takve suglasnosti i/ili dozvole ishoditi. Upitno je bi li takva dozvola mogla biti pravni osnov za pravno razdvajanje nepomičnog odobalnog objekta od nekretnine - morskog dna. 
na umu se treba imati i odredba čl. 36. st. 1.c PZ-a kojom je propisana dužnost osobe kojoj je dopuštena gradnja uređaja ili naprave ukloniti takav objekt u slučaju prestanka njegove uporabe i to u roku od 30 dana.

Za područje epikontinentalnog pojasa Konvencijom Ujedinjenih naroda o pravu mora ${ }^{47}$ obalnoj je državi dano isključivo pravo odobravanja i uređivanja bušenja u bilo koju svrhu (čl. 81.) te isključivo pravo graditi i dopuštati i uređivati izgradnju, rad i uporabu uređaja i naprava za te svrhe (arg. ex čl. 60. st. 1. Konvencije) što je implementirano i u PZ. U epikontinentalnom pojasu, koji obuhvaća morsko dno i morsko podzemlje izvan vanjske granice teritorijalnog mora, i u odnosu na koje područje Republika Hrvatska ostvaruje suverena prava upravo radi istraživanja i iskorištavanja njegovih prirodnih bogatstava pravno razdvajanje nepomičnog odobalnog objekta od zemljišne čestice - morskog dna bit će lakše realizirati ukoliko se i zauzme stav da su nepomični odobalni objekti nekretnine jer u tom području više ne djeluje zabrana uspostavljena ZPDML-om pa bi se i na odobalne objekte za istraživanje i eksploataciju imalo primijeniti opće stvarnopravno uređenje Republike Hrvatske.

Neovisno o tomu je li nepomični odobalni objekt za istraživanje i eksploataciju ugljikovodika iz podmorja pokretnina ili nekretnina na njega se neće primjenjivati odredbe PZ-a o izvanugovornoj odgovornosti, budući da se navedene odredbe primjenjuju samo na plovne objekte i hidroavion na vodi (čl. 809. PZ), a neće se primjenjivati niti odredbe o ograničenju odgovornosti. Pitanje izvanugovorne odgovornosti za štetu nastalu istraživanjem i eksploatacijom podmorja s nepomičnog odobalnog objekta rješavat će se primjenom općih pravila odštetnog prava sadržanih u Zakonu o obveznim odnosima $^{48}$ koji kao pravilo propisuje subjektivnu odgovornost (čl. 1045. st. 1. ZOO), a objektivnu odgovornost kao izuzetak, po kojem se odgovara za štetu od stvari ili djelatnosti od kojih potječe povećana opasnost štete za okolinu (čl. 1045. st. 3. ZOO) te u onim slučajevima kada je to zakonom propisano (čl. 1045. st. 4. ZOO). Zakonom nije izrijekom propisana objektivna odgovornost za štete nastale djelatnošću istraživanja i eksploatacije ugljikovodika iz podmorja, ${ }^{49},{ }^{50}$ a ni objekti s kojih se obavlja djelatnost istraživanja i eksploatacije ugljikovodika u morskom podzemlju nisu proglašeni opa-

$47 \quad$ NN-MU, br. 9/00 (u daljnjem tekstu: Konvencija).

48 NN, br. 35/05, 41/08, 125/11, 78/15. (u daljnjem tekstu: ZOO).

49 Objektivna odgovornost propisana je samo za ekološku štetu koju prouzroči fizička ili pravna osoba koja je bez pravne osnove izvodila rudarske radove ili izvan granica provjerenog rudarskog projekta (čl. 165. st. 1. i 2. ZR), dok se naknada ostalih vrsta šteta u tom slučaju obračunava na način propisan odredbama obveznog prava i posebnim propisima (čl. 165. st. 4. ZR). Bivšim zakonima o rudarstvu (iz 1991. i 2009.) bila je propisana objektivna odgovornost (prvo rudarskog poduzeća i samostalnog poduzetnika, potom ZID ZR-a trgovačkog društva i obrtnika te zakonom iz 2009. nositelja odobrenja za istraživanje mineralnih sirovina i koncesionara za eksploataciju mineralnih sirovina.

50 Popis djelatnosti koje se smatraju opasnima za okoliš nalazi se u Prilogu I Uredbe o načinu utvrđivanja štete u okolišu, NN, br. 139/08, 80/13. Navedenom Uredbom djelatnost istraživanja i eksploatacije ugljikovodika nije izrijekom navedena kao opasna. Time se ne isključuje mogućnost da se ona u postupku utvrdi opasnom, ali se isključuje primjena Uredbe (arg. ex čl. 3. Uredbe). 
snim stvarima niti su djelatnosti istraživanja i eksploatacije ugljikovodika iz morskog podzemlja proglašene opasnim djelatnostima. Stoga će sud, u slučaju nastanka štete i postavljanja zahtjeva za njezinom naknadom, u prvom redu morati odrediti je li takav nepomičan odobalni objekt opasna stvar, odnosno je li djelatnost istraživanja i eksploatacije ugljikovodika u morskom podzemlju opasna djelatnost od kojih je prijetio povećan rizik nastanka štete. Ukoliko bi sud ocijenio da nepokretna platforma nije opasna stvar i da djelatnost istraživanja i eksploatacije ugljikovodika iz podmorja nije opasna djelatnost, trebao bi primijeniti pravila o subjektivnoj odgovornosti, odnosno predmnijevanoj krivnji, što bi imalo za posljedicu da izvođač djelatnosti ne odgovara ukoliko dokaže da nije kriv, odnosno ne odgovara za slučajne štete. Ako bi sud utvrdio postojanje odgovornosti (neovisno o tomu da li primjenom pravila o predmnijevanoj krivnji ili na temelju relativnog kauzaliteta) izvođač djelatnosti odgovarao bi neograničeno. Držimo da bi svakako bilo oportuno za štete nastale tim djelatnostima zakonom izrijekom propisati odgovornost po načelu relativnog kauzaliteta.

\section{Zaključno o pravnim implikacijama nedoslijednog pravnog statusa odobalnih objekata za istraživanje i eksploataciju ugljikovodika}

Svrha ovoga rada je ukazati na pravne praznine zakonskog okvira kojim je uređena djelatnost istraživanja i eksploatacije ugljikovodika iz podmorja te pravne implikacije do kojih može doći uslijed popunjavanja tih praznina supsidijarnim zakonima. Naime, ZIEU je propustio propisati niz aspekata i mogućih situacija, već je umjesto sustavnog normiranja uputio na primjenu ZR-a. Oba zakona, međutim, uređuju djelatnost istraživanja i eksploatacije, kao i same objekte za istraživanje i eksploataciju, na jedinstven način, neovisno o tomu da li se ta djelatnost obavlja na kopnu ili moru. Zakonodavac je prilikom donošenja tih zakona, u prvom redu, imao na umu kopnena istraživanja i objekte, dok je odobalne objekte obuhvatio samo formalno, ne vodeći pri tomu računa o posebnostima područja na kojem se te djelatnosti izvode (nepostojanje katastra pomorskog dobra, nepostojanje granica između JLS-a na moru, činjenica da je morsko dno i podmorje teritorijalnog mora u režimu općeg dobra, osjetljivost morskog okoliša...) kao niti o specifičnosti odobalnih objekata (njihove tehničke raznolikosti uz koju je vezana problematika njihova podvođenja pod kategorije pomorskih objekata predviđenih PZ-om). Složenosti prijepornih pitanja pridonosi i terminološka neujednačenost između temeljnih zakona, što ostavlja prostora za podvođenje istog objekta pod različite kategorije. Neujednačenost terminologije i podnormiranost materije otvara opasnost da primjena supsidijarnih propisa koji nisu prilagođeni potrebama istraživanja i eksploatacije ugljikovodika u podmorju izazove neočekivane i neželjene pravne učinke.

Primjerice, odredbe o građevinskoj dozvoli, propisane u prvom redu za kopnene rudarske objekte i postrojenja, pokazale su se, u dijelu u kojem se kao uvjet za ishođenje te dozvole traži dokaz o plaćanju komunalnog i vodnog doprinosa, neprimjenjivima. Čini se da bi, za odobalne objekte bilo svrsishodnije umjesto tih naknada, čija zakonitost 
je upitna, propisati posebnu vrstu doprinosa, pod nekim novim nazivom, uz određivanje osobe kojoj ta naknada treba biti plaćena.

Zakonski okvir kojim je uređena materija istraživanja i eksploatacije ugljikovodika ne sadrži pravila o naknadi izvanugovorne štete koja može nastati takvim djelatnostima. Stoga do odgovora na pitanje tko će, na kojem pravnom temelju, za što i do koje visine odgovarati dolazimo primjenom dvaju različitih zakona - primjenom odredaba PZ-a na pokretne platforme i bušaće brodove, a općih propisa građanskog prava na nepokretne platforme. Posljedica primjene različitih propisa je nejednak režim odgovornosti za iste vrste šteta. Svakako bi za ove djelatnosti, neovisno s kojeg se objekta izvode trebalo propisati isti režim odgovornosti, i to po načelu relativnog kauzaliteta. Nepovoljne su i zabrinjavajuće i pravne posljedice tretiranja dijela odobalnih objekata za istraživanje i eksploataciju ugljikovodika (bušaćih brodova) kao brodova i to zbog postojanja instituta ograničene odgovornosti, koja se utvrđuje i izračunava po bruto tonaži broda, što je posve neprimjereno jer eventualna šteta može višestruko premašiti iznos naknade štete. S druge strane, za istu štetu koju bi uzrokovala plovna platforma ili nepomični odobalni objekt za istraživanje i eksploataciju podmorja ne bi uopće bilo moguće ograničiti odgovornost. Do tog zaključka dolazimo primjenom dvaju različitih propisa - Pomorskog zakonika u odnosu na plovne platforme, odnosno ZOO-a u odnosu na nepomične odobalne objekte. Postojanje takvih dvostrukih, međusobno bitno neusklađenih, režima, štetno je i neprihvatljivo. Na to se pitanje nadovezuje i problem osiguranja odgovornosti, odnosno (ne)osigurljivosti rizika od odgovornosti u slučajevima kada zakonom nije propisano ograničenje odgovornosti. ZIEU-om vrlo je uopćeno propisana obveza davanja financijskog jamstva pa ostaje nejasno bi li tim jamstvom uopće bile pokrivene obveze iz izvanugovorne odgovornosti.

Osim necjelovitih odredaba o izvanugovornoj odgovornosti, prijeporna je i odredba kojom ZIEU omogućava relativno lagan prijenos prava vlasništva na rudarskim objektima s investitora na Republiku Hrvatsku (čl. 25. st. 1 i 2 ZIEU). Štoviše, u nekim je slučajevima propisano ex lege stjecanje, dakle, stjecanje bez volje države da postane vlasnikom, pri čemu se zanemaruje okolnost da vlasništvo, osim ekonomskih probitaka, uključuje i odgovornost. Odredbom čl. 25. st. 2. ZIEU propisano je da u slučaju ukidanja dozvole i/ili raskida ugovora bez obzira na razloge ukidanja i/ili raskida, odnosno isteka dozvole i/ili ugovora bilo koja nepokretna imovina ili konstrukcija neodvojiva od nepokretne imovine $u$ istražnom prostoru i/ili eksploatacijskom polju postaje vlasništvo Republike Hrvatske i to bez obzira da li su takvi troškovi nadoknađeni ili ne tijekom trajanja dozvole i/ili ugovora. Stavkom 1. istog članka predviđena je mogućnost prelaska prava vlasništva rudarskih objekata na RH i u postupku povrata troškova. Ta se odredba ne bi trebala odnositi na rudarske objekte na moru, budući da platforme od drugih stacioniranih postrojenja razlikuje upravo njihova mobilnost i mogućnost njihova rastavljanja na komponente. ${ }^{51}$ Trebalo bi je i izrijekom isključiti, kako se ne bi

$\overline{51}$ Matanović, D., Tehnika izrade bušotina, Priručnik s primjerima, Rudarsko-geološko-naftni fakultet, Sveučilište u Zagrebu, Zagreb 2007, str.1. 
pozivom na nju pokušalo prebaciti vlasništvo, a time i odgovornost za moguće štete, na Republiku Hrvatsku te je sustavno uskladiti s (još jednom kontradiktornom) odredbom čl. 36. st. 1. c PZ-a, kojom je propisano da je osoba kojoj je odobrena gradnja naprava na moru, morskom dnu i podzemlju dužna najkasnije u roku od 30 dana od dana prestanka gradnje ili uporabe, ukloniti svaki morski objekt koji se više ne uporablja ili je napušten, ne uzrokujući štetu ribolovu, zaštiti i očuvanju morskog okoliša ili drugim legitimnim uporabama mora.

Zbog svega navedenog nameće se zaključak o potrebi cjelovite i smislene dorade ZIEU-a na način da se posebnim odredbama uredi pravni status odobalnih objekata za istraživanje i eksploataciju, da se propišu uvjeti kojima se mora udovoljiti kako bi se mogla ishoditi građevinska dozvola za takav objekt, da se na prihvatljiv način regulira pitanje izvanugovorne odgovornosti za štetu te da se visina ograničenja odgovornosti za štete uredi na način da se uskladi potreba formiranja osigurljivog rizika s jedne strane i stvaranja fonda ograničene odgovornosti koji će ipak pokriti veći obim šteta.

Jedino prihvatljivo se čini rješenje prema kojem bi svi objekti za istraživanje i eksploataciju ugljikovodika bili podvrgnuti jedinstvenom režimu izvanugovorne odgovornosti za štetu, kojima bi bile obuhvaćene sve vrste šteta, s propisanim obveznim osiguranjem do granice odgovornosti propisane zakonom. Visina ograničenja svakako bi trebala biti razmjerna naravi rizika i potencijalnoj šteti te nevezana za bruto tonažu odobalnog objekta. Uvođenje obveznog osiguranja od odgovornosti trebalo bi biti praćeno i mogućnošću podnošenja direktne tužbe protiv osiguratelja.

Sveobuhvatni i koherentni pravni okvir te međusobno povezani i usklađeni propisi kojima bi se reguliralo djelatnosti istraživanja i eksploatacije ugljikovodika iz podmorja, umjesto postojećih fragmentarnih rješenja, nužan je za pravnu sigurnost, koja jamči najmanju mogućnost povrede opravdanih interesa ne samo za ugovorne strane, već i svih trećih. 


\title{
On some Aspects of the Legal Status of Offshore Objects for Exploration and Exploitation of Hydrocarbons in the Republic of Croatia
}

\begin{abstract}
The purpose of this paper is to examine and determine the legal status of offshore facilities for exploration and exploitation of hydrocarbons according to the Croatian law. The analysis of the provisions of The Act on Exploration and Exploitation of Hydrocarbons regulating those activities showed that the legal status of these objects is not determinate. The fact imposed the need for provisions to be introduced in order to determine the legal status of those structures. The explicit determination of the legal status of different offshore facilities for exploration and exploitation of hydrocarbons from the seabed is of great importance not only for potential investors, the existing concessioners and the Republic of Croatia, but also for third parties, considering that it is the legal status of offshore objects that, for example, the application of provisions on tort depend upon.

The author points out that exploration and exploitation of hydrocarbons from the subsoil can be carried out from the offshore facilities which are, by their technical characteristics, different to the extent that it is questionable whether the same legal regime could be applied to all of them. Furthermore, the very same object could be classified differently depending on whether it is in the function of exploration and exploitation of hydrocarbons or in the process of relocation.

Taking into account the above stated, the author analyses the issue of whether in each particular case provisions of the Mining Act, governing the status of mining facilities, or provisions of the Maritime Code, since the activity is carried at sea, should apply. In the case of application of the Mining Act, those structures would be considered immovable property. The Maritime Code, on the other hand, distinguishes between three types of marine facilities - a vessel (ship), floating facility and fixed offshore structure, where from there emerges a sub-question asking which of the afore named types of maritime facilities the offshore facility for the exploration and exploitation of hydrocarbons should be classified. In order to determine the legal status of each offshore object as movable or immovable property, provisions of the lex generalis - Act on ownership and other real rights are consulted as well. The purpose of this article is to point out the legal gaps of the current legal framework and to forewarn on possible unexpected and adverse legal effects of filling those legal gaps by subsidiary regulations, not adjusted to specific features of those activities. In order to reduce the current legal uncertainty, legal status of those facilities should be precisely regulated in one place - which is the Act on Exploration and Exploitation of Hydrocarbons.
\end{abstract}

Keywords: legal status, platform, offshore unit, exploration and exploitation of hydrocarbons 